\title{
THE CONSUMER LOYALTY FORMATION PROCESS AND ITS PARTICULARITIES IN THE RETAIL SECTOR
}

\author{
Iveta Liniṇa ${ }^{1}$, Rosita Zvirgzdiṇa ${ }^{2}$ \\ Faculty of Business Administration, Turiba University, Graudu street 68, Riga, LV-1058, Latvia \\ E-mails: ${ }^{1}$ veta.linina@turiba.lv(correspondingauthor); ${ }^{2}$ rosita@turiba.lv
}

\begin{abstract}
Retail sector has always played and important role in the national economy. Any business is tendet towards satisfaction of consumer desires and needs, albeit profits. In relationships between companies and consumers both sides have their interests. For a company it, primary, is to increase the turnover and make profits, while the consumers may have several goals - to obtain the goods or services, to receive the necessary information and attitude. These consumer benefits are the basis for loyalty. Thus, the aim of the present paper is to research the loyalty formation process and its characteristics in the retail sector.
\end{abstract}

Keywords: consumer, consumer satisfaction, consumer loyalty, loyality process, consumer relationship management, retail.

JEL Classification: M5; M31.

\section{Introduction}

In the contemporary product-saturated market environment, it is vital to ensure competitiveness. Consumer orientation, their needs research and satisfaction focusses on the application of consumer relationship management in the company. The costumer satisfaction and its management have become an integral part of business. Recent research shows that the acquisition of new consumers is 5 to 10 times more expensive than selling to the existing consumers, and the existing consumers spend $67 \%$ more money than the new ones (Anderson et al. 2007). Therefore, a company has to develop a system for creating consumers' desire for repeated purchasing and for ensuring uninterrupted relationships with them. By attaining understanding on the factors contributing to consumer loyalty and by applying them effectively, the company promotes consumers' trust and significantly increases its own competitiveness. When researched and understood correctly, the consumer satisfaction factors form a significant competitive advantage of the company. The companies in the Baltic States do not possess sufficient understanding on the consumer relationship management and, especially, its benefits. Thus, the present paper focusses on the factors contributing to consumer loyalty formation.

The research covers the most common consumer loyalty models, nevertheless, it should be noted that the consumer loyalty formation process never finishes, and is largely regarded as a mechanism for company improvement. While companies use various consumer management systems, the unifying criterion is the objective of a satisfied and loyal consumer, which would ensure long-term competitiveness.

The aim of the research is to approximate the main consumer loyalty formation factors in the retail sector and to define the specific characteristics of the process, which would allow the retailers to improve their operation and ensure competitiveness in real-life situations.

To reach the aim, the following tasks were drawn:

1. To analyse the theoretical factors of consumer loyalty formation.

2. To describe the retail sector and its development in the Baltic States.

3. To carry out a survey to establish the main consumer loyalty formation factors and their peculiarities in the retail sector.

To establish the consumer loyalty trends in the Baltic States and to draw suggestions for companies on the improvement of consumer loyalty formation processes, there was carried out a consumer survey and the following limitations were established: the research scope includes mainly the methodological aspects and the demographic indicators (e.g. the education level, the age, the domicile etc.) of the respondents are not taken into account. The research period is from January 1, 2015, to January 1, 2016. 
The following research methods were applied: logically-constructive method for the comparison of the theoretical material with the empirical study results, graphic-visual method for the depiction and analysis of the gathered information, and a consumer survey. The methodological basis is the works and publications of foreign authors (Oliver 1994; Westbrook, Reily 1983; Howard, Sheth 1969; etc.), which provide insight on consumer relationship formation factors and process.

\section{Theoretical aspects of consumer loyalty formation}

Consumer satisfaction is one of the preconditions for long-term and profitable relationship formation between companies and consumers. Consumer satisfaction forms within a dynamic comparison process, and consumer satisfaction or dissatisfaction depends on the level at which the consumer expectations are (or are not) fulfilled. The consumer satisfaction level may have different expressions in the consumer behaviour on the market, which also influences company success.

Loyalty is one of the most important expressions of satisfaction. The acquisition of new consumers costs significantly more for companies than the retention of the existing consumers, as the existing consumers spend more but cost less (Karjaluoto et al. 2012). Some researchers have concluded that the retention of the loyal consumers involve $15-20 \%$ less expenses than what is needed to acquire new ones (Mueller, Riesenbeck 1991). Meanwhile, on the basis of applied research, other researchers claim that the acquisition of new consumers costs 5-7 times more than the retention of the existing ones (Hermann, Huber 1997).

In the end of the $20^{\text {th }}$ century and in the $21^{\text {st }}$ century the research on the loyalty and its practical application have been influenced by the publications of Oliver (1997). He does not argue against the statement that the loyalty formation process largely depends on the consumer satisfaction, nevertheless he indicates that the loyalty has four dimensions, namely - cognitive loyalty, affective loyalty, conative loyalty and behavioral loyalty, which together influence the decision on repeated purchase.

In general, most of the applied research (Mittal, Kamakura 2001; Jones, Sasser 1995) shows a close correlation between consumer satisfaction and loyalty. Yet, so far there has not been reached an agreement on real-life (progressive, regressive or other) expressions of this correlation. Some of the researchers believe that the correlation may depend on market situation, offer characteristics and specifics of the target groups. There has been substantiated that in the markets with intense competition the correlation between consumer satisfaction and loyalty is characterized by a progressive graphic form, but in the markets with a relatively low competition intensity it has a regressive graphic form (Jones, Sasser 1995; Homburg, Giering 2000; Homburg, Rudolph 2001). Applied research shows that consumer satisfaction and loyalty form a relationship that may be depicted graphically in $\mathrm{S}$ form. Only when the consumer has been infatuated, the loyalty increases very rapidly, it is stable when the consumer is indifferent, and disappointment leads to decrease in loyalty (Matzler, Pechlaner 2001). Other researchers have concluded that sometimes somewhat illogical situations arise when satisfied consumers are disloyal, and unsatisfied consumers are still loyal (Finkelmann, Goland 1990; Cano et al. 2001).

Summarizing the given opinions on correlation forms between consumer satisfaction and loyalty, the authors established four levels of loyalty:

- Unreal loyalty forms when the consumer is not satisfied with the offer but is still loyal. This may happen in case when the consumer continues to do repeated purchases due to convenient outlet, established habits or constant offer or relatively low prices. The company has to establish the reasons for dissatisfaction and eliminate deficiencies.

- Lack of loyalty is when the consumer is not satisfied with the offer. It may happen when the other loyalty factors do not function, when unreal loyalty is being formed or when the consumer has only a small consumption/using experience and a stable attitude and action loyalty has not formed yet. The company has to work in two directions: to eliminate the reasons for dissatisfaction and to carry out measures to increase consumer loyalty.

- True loyalty forms when the consumers satisfied with the offer are also loyal. It means that they make repeated purchases, are less perceptive of price fluctuations, and carry out a positive word-of-mouth communication on the product, brand, or company.

- Prospective loyalty forms when, irrespective of satisfaction and positive consumption or experience of use, there is a relatively small number of repeated purchases and other loyalty attributes do not function. 
This may happen when consumers prefer the variety of offer to ensure changes in consumption (such behaviour referred to as variety seeking). The company has to design (or develop) special loyalty programmes for closer attraction of consumers.

In the analysis of the satisfaction-loyalty correlation, other authors highlight six consumer loyalty levels (Cartwright 2000):

1. Consumer - apostles has expressed loyalty as he has the highest satisfaction with the product/brand, is able to identify the company, and has the highest level of belonging. This type of consumer is always ready to provide recommendations to their friends and acquaintances. Nevertheless, when this consumer begins to experience too large a belonging to a company and there happens something making him unsatisfied, he becomes disloyal.

2. Consumer - loyalist is the main target audience for any company. This consumer does not require increased participation from the company, as it is expected by a consumer-apostles. He has a very high loyalty level and tolerates to larger extent the mistakes and offer deficiencies of the company. If a loyalist loses confidence in the offer/company, it means that the company is in substantial trouble. Loyalists are stable and objective judges and may form useful focus groups.

3. Consumer - mercenary typically strives for a cheaper and easier option. Therefore, the consumer may be satisfied with the offer, but it will not mean that he is loyal. It may be very hard for a company to turn a consumer-mercenary into a consumerloyalist as it requires much work and resources. Even by constant offer of discounts for products/brands, a company risks attracting consumers-mercenaries instead of loyal consumers.

4. Consumer - hostage does not have any alternative, thus his loyalty is not true. It forms only because the consumer does not have a chance to choose other offer. When such a chance appears, this unsatisfied consumer will immediately move to obtain a higher level of satisfaction.

5. Consumer - deserter is not satisfied and therefore turns from a loyal consumer into a disloyal one. This sometimes happens despite the fact that the offer has not changed. Such behaviour derives from the wish to find something new and depends largely on internal feelings.

6. Consumer - terrorist is not satisfied with the offer and therefore tries to harm the company (writes complains, litigates etc.). It is much easier for the company to give up such a consumer than to condescend and inflict loss.

In essence, any target group may be divided by the before-mentioned levels of loyalty. Furthermore, other authors offer loyalty level criteria, which are not connected with satisfaction and are related only to loyal consumers. For example Stahl (2006) distinguishes three groups:

1) Changeable loyalty - is characterised only by repeated purchases, but other expressions of loyalty are not observed at all or in a very small extent.

2) Stable loyalty - is characterised by several consumer loyalty expressions (e.g. recommendations to other consumers, participation in company's events etc.), nevertheless, when the conditions change (e.g. the prices increase), these consumers may leave.

3) Persistent loyalty - is characterised not only by different loyalty expressions, but also by such a trust, cognitive and emotional level that excludes any possibility of moving to competitors.

The results of the research on satisfactionloyalty correlation show that the relationship is contradictory. The consumer loyalty does not derive directly from consumer satisfaction, but requires management and marketing measures, social events etc.

Contrary to the $20^{\text {th }}$ century research, the scientists in the $21^{\text {st }}$ century mainly include satisfaction as a part of loyalty formation process, irrespective of the research object. Meanwhile, nearly all the authors draw conclusions on particular process particularities dependant on the characteristics of the industry, product or brand. Let's have a look at the study of mobile service client satisfaction and loyalty in China, based on a survey of 541 respondents, $80 \%$ of which had a higher education. The authors draw the following conclusions:

1) Trust, service quality and perceived value significantly influence customer satisfaction.

2) Satisfaction and costs significantly influence customer loyalty.

3) Among perceived values, the satisfaction is mostly influenced by functional and 
emotional values, while social and monetary values create a smaller impact (Deng et al. 2010).

The authors believe that the model may be applied in the research of other industries, products or brands, taking into account their specifics, but, as mentioned earlier, trust and emotional value refer to the dimensions of loyalty, not to the influencing factors. The issue of customer expenses is also questionable. It may be useless to depict this indicator separately as the monetary value itself includes the comparison of the consumption effect and the expense aspect.

In Norway, there has been created a special consumer satisfaction and loyalty measurement rating (EPSI) based on the corresponding model (see Fig. 1). The model indicates that the consumer perceived values include company image, value offer expected by the consumer, real quality of the product and service quality. These perceived values determine satisfaction and the resultant consumer loyalty (Pervaiz, Sudha 2007).

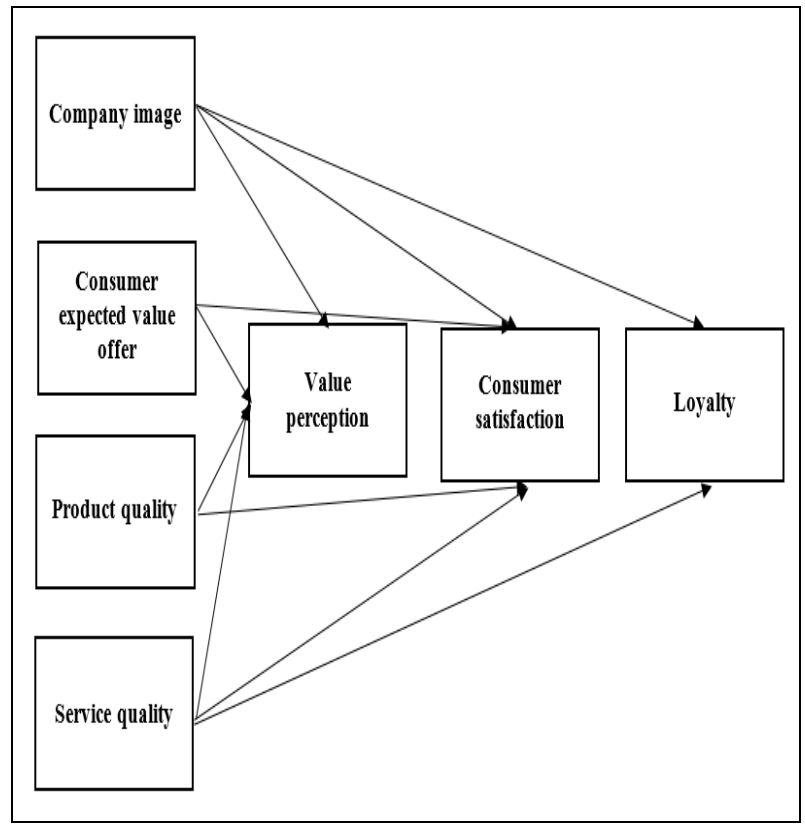

Fig. 1. Loyalty model according to the EPSI rating (Source: Pervaiz, Sudha 2007)

Firstly, the model assumes that all satisfaction influencing factors may also have a direct impact, i.e. without consumer perception. The authors believe that this may refer to consumers with high level loyalty, when the choice of the offer in the prepurchase stage takes place nearly automatically.

Secondly, the company image and service quality may directly affect loyalty even without the satisfaction stage. Obviously, such relationship also depends on the consumer loyalty level, name- ly, the higher it is, the smaller the significance of satisfaction in the process.

Unfortunately, the model's authors have not depicted the dimensions of loyalty. Maybe, resultant to study of loyalty attitude and action dimensions, there might have appeared other conclusions on the direct impact on loyalty. The authors of the present paper neither agree with the assumption that the consumer expectations regarding value offer refer to values influencing satisfaction as, before the establishment of satisfaction/dissatisfaction, there takes place the comparison of the actual and expected offers, and this, to great extent psychological process, is connected with the consumer perception. At the same time, the omission of the monetary value (ratio of the offered price against consumer expenses) from the model lacks substantiation.

As it can be seen, the consumer loyalty formation processes include the following logicallyinterrelated elements:

1) Loyalty influencing factors (values).

2) Consumer value perception.

3) Perceiving group's characteristics.

4) Consumer satisfaction.

5) Consumer loyalty dimensions.

Summarizing the theoretical aspects of the concept of loyalty, the authors offer the following definition of loyalty.

Loyalty is the result of the consumer perception of the offer (of goods, services, brand etc.) that has led to a positive attitude (cognitive, trust and emotional) and to an action beneficial for the company (repeated purchase, extra purchase, high consumption intensity, etc.).

\section{Retail sector and its development particulari- ties in the Baltic States}

The scientific literature review shows that there exist satisfaction formation process and loylity differences in three sectors of national economy: sector of consumer goods (Swan, Combs 1976; Lewis 1995; etc.), sector of industrial goods (Homburg, Rudolph 2001), and sector of services (Brandt 1988; Cadotte, Turgeon 1988). The research object of the present study - retail sector - due to its specifics can not be included in any of these sectors, therefore it is useful to highlight its particularities in the context of satisfaction.

Retail is an intermediary (distribution channel) between producers and/or wholesalers, who supplies goods, and consumers. Thus, to satisfy consumer needs, retail has to influence producers 
and wholesalers (orders, deals), as well as to cooperate with them.

1) Retail adds a particular value to material products - goods, as there is also carried out sorting, weighting, packing etc. Even by selling the goods produced by other companies under own brand, retailers add a certain value.

2) Retail provides consumer service within their market of operation in traditional shops, outside them and by using internet sites. Retail provides service or immaterial product complex, which cannot be transferred to consumers as a property.

The retail characteristics provide that consumers have to be satisfied both by material (goods) and immaterial (services) products. This impacts nearly all process of satisfaction and loyalty formation. The level and intensity of the influence depends of the level of service (supermarket or exclusive shop etc.), form of trade (traditional shop, off-site trade) and other factors.

Private consumption is one of the cornerstones of economic growth and retail may be considered an indicator of state's economic growth. Since the restoration of independence, the retail sector in Latvia, the same as in all Baltic States, has developed with changeable consequences. It has been one of the major contributors to the GDP. In many ways it has been dependent on the countries' willingness to organize this sector. The retail transferred from outdoor markets, sports halls and sheds to shops and supermarkets. During the global economic crisis, the retail was one of the national economy sectors to experience the largest decrease. To explain the deterioration of such a scale, there should be noted many different aspects, but among the primary ones was the disruption in consumer crediting. During the stabilisation of the economic condition in the country, the retail sector also started to improve (see Fig. 2).

Since 2011, the retail sector in the Baltic States has been following the development trend of the economy in general (see Fig. 2). The retail sector depends mostly directly on the internal (national) events, nevertheless it is influenced indirectly also by external environment factors. The RussiaUkraine conflict and the related sanctions, as well as the recent weak growth rates in the European Union (EU) has left a negative impact on consumer activity and promoted savings, slowing down the overall consumption. However, the data on labour market and salaries allow assuming that internal market development is still resisting successfully

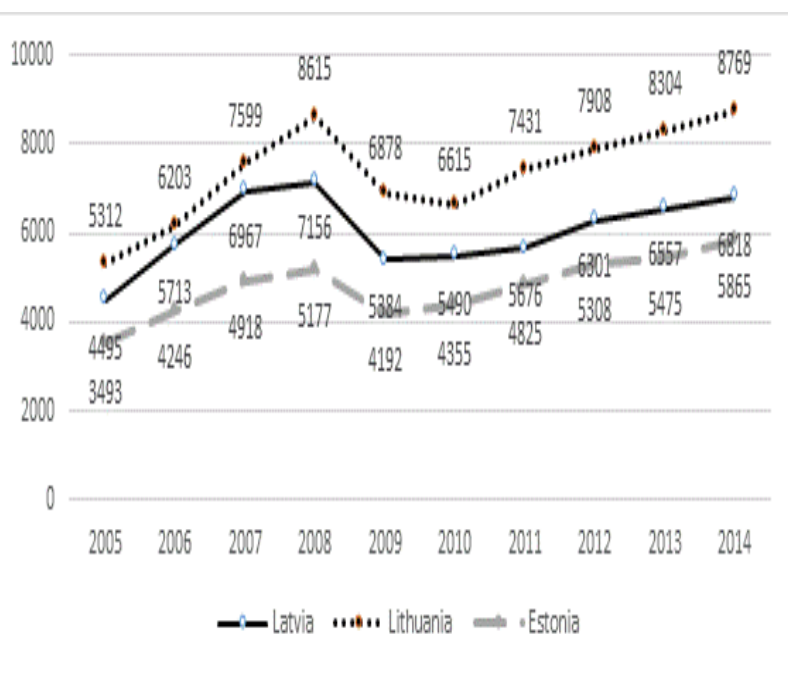

Fig. 2. Retail turnover 2005-2014 in the Baltic States (millions EUR, comparable prices) (Source: compiled by the authors, according to CSP informativais... 2015; Retail turnover... 2015)

the negative impacts of external environment (CSP informativais... 2015).

Despite the current overall retail growth rates, the internal competition within the sector keeps increasing. Unfortunately many companies in order to increase their competitiveness chose non-legal and/or unfair means in reaching their goals. It can been seen in recent research devotet to so-called shadow economu index (SEI), that is calculated on the basis of Gross domestic product (GDP), where the retail index takes the second place after the construction industry (Putnins, Sauka 2015). Therefore, the retailers need an instrument to ensure competitiveness and create consumer desire for repeated purchase, so that they would not interrupt relationships with the company, product or brand.

\section{Consumer loyalty formation factors and its particularities in retail}

To identify consumer satisfaction factors, which may serve as basis for loyalty formation, and to rage them according to their significance in retail, there was carried out a consumer survey in all three Baltic States. The survey was designed in Google Forms, and translated into Lithuanian and Estonian to ensure the speakers of these languages with an opportunity to participate. Further, applying non-probability snowball method, the link to the questionnaire was e-mailed to recipients on the authors' personal contact list, who forwarded the message further. The questionnaire was also distributed to the member-companies of the trade associations in all three Baltic States. The survey 
respondents totalled to 738 respondents aged 18 to 74 , including $65 \%$ women and $35 \%$ men. Regarding segmentation of the respondents by income level, the different income groups were distributed equally.

The survey data analysis results indicate the respondent habits and it may be concluded that $87 \%$ shop in several chains of supermarkets, $12 \%$ - in two chains, while only $1 \%$ prefer shopping in a particular chain of supermarkets. $72 \%$ of respondents shop several times a week and at the same outlets. On average, they spend 15 to 30 minutes in the shop. In particular cases, these regular consumers $(68 \%)$ may shop in other chains following discounts and attractive offers. Information on the offers is acquired in many different ways. The most frequent answers mentioned by respondents included weekly discount newspapers, recommendations of relatives, friends and neighbours, as well as advertising. $90 \%$ of the respondents use several loyalty/discount cards offered by traders and their attitude towards them is positive. At the same time, $64 \%$ of loyalty/discount card users admitted that the trading companies never or hardly ever allow for communication via mobile text messages or e-mail. Even when such communication exists, it is not customised.

Regarding the question on factors related to what is important while choosing where to shop, the most important factor mentioned was the location of the shop. As in all three Baltic States the trading area per one inhabitant has not reached the average European indicators, this is understandable. Ranging other factors by their importance, it can be seen that 4 points were gained by product range/trademarks and price level, followed by service quality, while marketing activities and loyalty programmes were mentioned as the least important factors (see Fig. 3).

Summarizing the shop evaluation factors, which according to the survey results would ensure consumer satisfaction, the situation is as follows (see Fig. 3): the respondents value the most the location of the goods and convenience, followed by price level, marketing activities and loyalty programmes, while the lowest evaluation gained customer service quality and product range/trademarks.

It must be noted that the higher scores in the figure correspond to the more positive evaluation, while the lower scores - to the worse ones. Comparing both graphs (see Fig. 3), there may be drawn a conclusion on the mismatch between the criteria evaluation by their value for consumers and the real operation of the supermarkets. For ex- ample, an important criterion - product range/ trademarks (4 points) - was evaluated with score of 1 point by the real operation. The research shows that not only the goods/trademarks ensure consumer satisfaction, but also many other factors connected with the whole process at both the prepurchase and purchasing stages. Thus, it may be concluded that the consumer satisfaction formation process in retail is a complex process consisting of several stages, where each of them impacts the formation of satisfaction and loyalty.

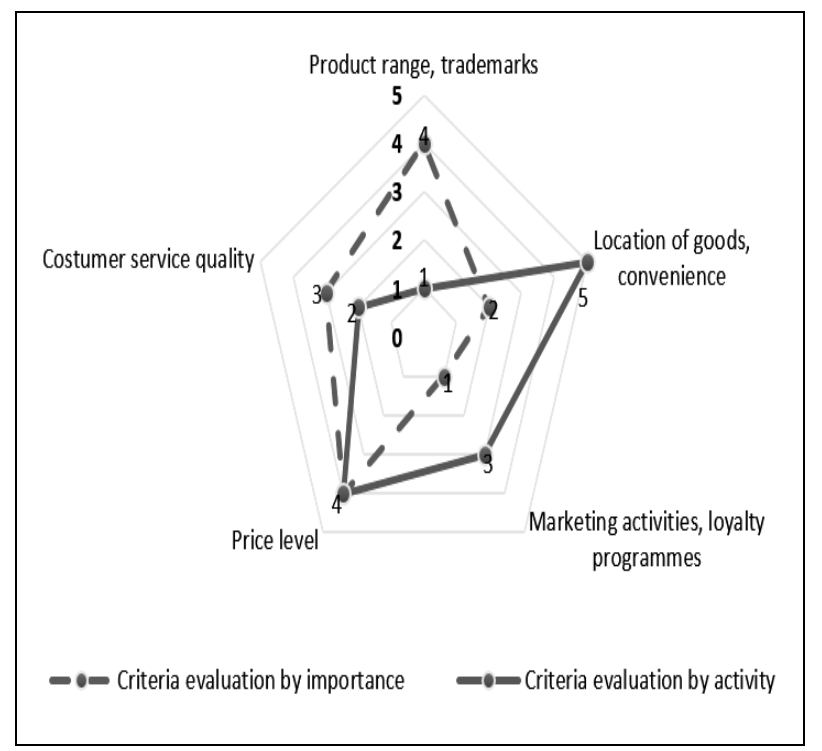

Fig. 3. Supermarket choice criteria and operation evaluation by consumers (Source: created by the authors)

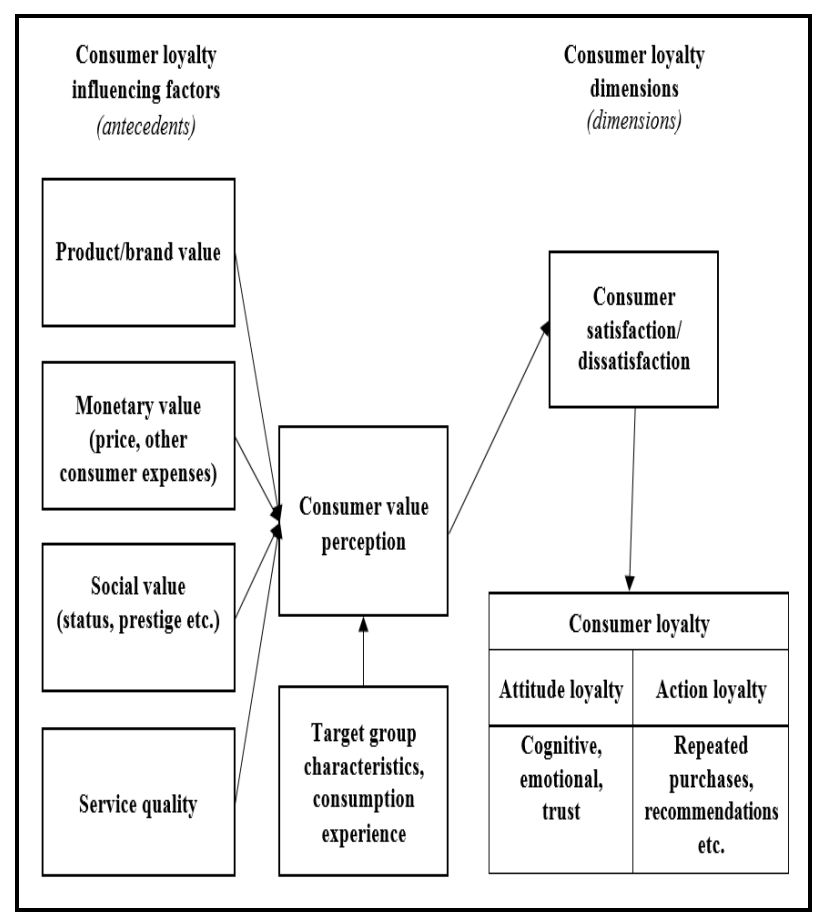

Fig. 4. Conceptual consumer loyalty formation model (Source: created by the authors) 
On the basis of the research results and the analysis of loyalty model advantages and disadvantages, the authors designed and offer for applied use a conceptual consumer loyalty formation model (see Fig. 4).

This model is fundamentally universal, but should be applied in practice taking into account the specifics of the sector, product or brand. The authors believe that the loyalty model (see Fig. 4) should be regarded as basis for consumer relationship formation and management process.

\section{Conclusions and recommendations}

On the basis of the study and specialized literature analysis, the following retail consumer loyalty formation model's particularities may be highlighted:

1) The consumer may be loyal to a particular outlet (shop, off-site trade, e-commerce etc.) mainly because of the following factors:

- trade in the product/brand that the customer is satisfied with;

- satisfaction with the product/brand value consumer expenses ratio;

- satisfaction with the service quality;

- social factors have a relatively lower impact (except for the exclusive shop customers);

2) The perception of the three abovementioned factors depends on the characteristics of the target groups, as the factors may have different value, significance and priority. For example, it is still possible that, despite the reasonable prices and high service quality, the consumer will not be loyal if he does not find the needed products/brands.

3) Contrary to other sectors, the retail sector may have a relatively large ratio of unreal loyal consumers (who make purchases only because of convenient location of the shop) and prospectively loyal consumers (who are satisfied, yet do not make repeated purchases, as they pay more attention to the sales and discounts).

4) The attitude loyalty mainly refers to product/brand value and to the ratio between the product/brand value and the consumer expenses, while the action loyalty - to the service quality. Thus, both of these loyalty dimensions should be closely regarded.

5) The consequences of consumer loyalty differ, yet its main expression is repeated purchasing. Other expressions of loyalty low price sensitivity and positive word-ofmouth communication - are less characteristic as they do not refer to retail in general, but to particular products/brands in particular.

The retail sector is one of the most important contributors to GDP and it develops similarly in all three Baltic States. The consumer loyalty in the retail sector should be regarded in more detail than in other business sectors, as not only the consumption has to be taken into account, but also other process factors, e.g. the location of the outlet, service quality etc.

With the growing competition in retail, it is important to understand all the factors that may increase the competitiveness. A loyal consumer is the key to the retail business success. Thus, it is important to develop an action plan for the improvement of these factors within the CRM (consumer relationship management) system.

\section{References}

Anderson, J. L.; Jolly, L. D.; Fairhurst, A. E. 2007. Customer relationship management in retailing: a content analysis of retail trade journals, Journal of Retailing and Consumer Services 14(6): 394-399. http://dx.doi.org/10.1016/j.jretconser.2007.02.009

Brandt, R. 1988. How service marketers care identify value - enhancing service elements, Journal of Services Marketing 2(3): 35-41. http://dx.doi.org/10.1108/eb024732

Cadotte, E.; Turgeon, N. 1988. Dissatisfiers and satisfiers: suggestions from customer complaints and compliments, Journal of Consumer Satisfaction Dissatisfaction and Complaining Behavior 1: 7479.

Cano, M.; Drummond, S.; Miller, C.; Barclay, S. 2001. Learning from others: benchmarking in diverse tourism enterprises, Total Quality Management 12(7-8): 976-983.

http://dx.doi.org/10.1080/09544120100000023

Cartwright, R. I. 2000. Mastering customer relations. Palgrave Macmillan.

CSP informativais apskats 2015 [online], [cited $23 \mathrm{Fe}-$ bruary 2016.]. Available from Internet:

http://www.csb.gov.lv/search/ apachesolr_search/ CSB\%20statistikas\%20parskats\%202015

Deng, Z.; Yaobin, Lu.; Kwo, K. W.; Iinlong, Z. 2010. Understanding customer satisfaction and loyalty: anempirical study of mobile instant messages in China, International Journal of Information Management 30: 289-300.

http://dx.doi.org/10.1016/j.ijinfomgt.2009.10.001

Finkelmann, D.; Goland, A. 1990. Information strategy, The Executives Journal 6(4): 5-10. 
Hermann, A.; Huber, F. 1997. Kundenloyalitat Deserfolgsdeterminante im Marketing, Journal fur Betriebswirts-chaft 47(1): 4-25.

Homburg, C.; Giering, A. 2000. Kundenzufriedenheit: ein Garant fur Kundenloyalitat?, Absatzwirtschaft 1-2: 82-91. http://dx.doi.org/10.1016/S0148-2963(99)00101-0

Homburg, C.; Rudolph, B. 2001. Customer satisfaction in industrial market: dimensional and multi role issues, Journal of Business Research 52(1): 15-33.

Howard, J.; Sheth, J. 1969. The teory of buyer behavior. New York: John Wiley and Sons.

Jones, T.; Sasser, W. 1995. Why satisfied customer defect, Harvard Business Review 73(6): 88-99.

Karjaluoto, H.; Jayawardhenda, C.; Leppaniemi, M.; Pihestrom, M. 2012. How value and trust influence loyalty in wireless telecommunications industry, Telecommunications Policy 36(8): 636-649. http://dx.doi.org/10.1016/j.telpol.2012.04.012

Lewis, B. 1995. Measuring consumer expectation and satisfaction, in: R. Brookes (Ed.). Customer satisfaction research. Amsterdam.

Matzler, K.; Pechlaner, H. 2001. Management von Kundenzufriedenheit: 10 Trugschlusse. Vom Alten zum Neuen Tourismus. Beitrage aus Forschung und Prahis. Innsbruck: Studia Verlag.

Mittal, V.; Kamakura, W. A. 2001. Satisfaction, repurchase, intend and depurchase behavior: investigating the moderating effect on customer characteristics, Journal of Marketing Research 38(1): 131142. http://dx.doi.org/10.1509/jmkr.38.1.131.18832
Mueller, W.; Riesenbeck, H. J. 1991. Wie aus zerbriedenen Kunden auch anhaengliche Kunden Werden, Harvard Manager 3(13): 69-76.

Oliver, R. 1994. Whence consumer loyality?, Journal of Marketing 63: 33-44. http://dx.doi.org/10.2307/1252099

Oliver, R. 1997. Satisfaction: a behavioral perspective on the consumer. New York: Printce Hill.

Pervaiz, A.; Sudha, S. 2007. Online shopping - customer satisfaction and loyalty in Norway: Master's thesis. Blekinge Techniska Högskola, Norway.

Putnins, T. J.; Sauka, A. 2015. Enu ekonomikas indekss Baltijas valstis 2009-2014. Riga: SSE Riga.

Retail turnover 2005-2014 in the Baltic States. 2015 [online], [cited 25 February 2016]. Available from Internet: http://data.csb.gov.lv/pxweb/lv/rupnbuvn /rupnbuvn_ikgad_iekstirdz; http://pub.stat.ee/px-web.2001/Dialog/Saveshow. aspdatiem http://osp.stat.gov.lt/en/home

Stahl, H. 2006. Kundenloyalitat Kritisch Betrachtet. Kundenorientierte Unternehmensns Fuhrung. Wiesbaden: Gabler.

Swan, J.; Combs, L. 1976. Product performance and customer satisfaction: a new conception, Journal of Marketing 40(2): 25-33. http://dx.doi.org/10.2307/1251003

Westbrook, R.; Reily, M. 1983. Value-perceipt disparity: an alternative to the disconfirmation of expectations theory of consumer satistaction, Advances in Consumer Research 10: 256-261. 